Bangladesh J. Bot. 43(1): 59-64, 2014 (June)

\title{
EVALUATION OF GROWTH, YIELD AND QUALITY OF MAIZE AS INFLUENCED BY GENOTYPES AND NITROGEN LEVELS
}

\author{
Pradeep Singh, UN Shukla $^{1}$, Kaushal Kumar $^{1 *}$, Smita Singh ${ }^{1}$, V Kumar $^{1}$ \\ AND RAJEEV KUMAR ${ }^{2}$
}

Department of Agronomy, S.V.P.U.A \& T, Meerut-250 110, India

Key words: Evaluation, Genotypes, Nitrogen levels, Growth and yield

\begin{abstract}
Among genotypes, Dekalb 900 M Gold recorded significantly higher dry matter/plant, LAI, cobs placement height, grain yield, nitrogen content, protein content, protein yield and protein productivity than other genotypes. Leaves/plant and phytosynthetically active radiation (PAR) above canopy did not influenced by genotypes. Dry matter/plant, plant height, LAI, cobs placement height, protein content, protein yield and protein productivity exhibited higher under highest levels of nitrogen (160 kg N/ha), but at par with $120 \mathrm{~kg}$ $\mathrm{N} / \mathrm{ha}$. However, grain yield (6300 kg/ha) was highest under nitrogen levels of $120 \mathrm{~kg} / \mathrm{ha}$, but also at par with $160 \mathrm{~kg} \mathrm{~N} / \mathrm{ha}$ (6240 kg/ha). The effect of applied nitrogen was found non-significant in respect of leaves/plant, PAR above and below canopy, photosynthetically active radiation interception and days taken to tasseling and silking.
\end{abstract}

\section{Introduction}

Among cereals, maize (Zea mays L.) is an important food and feed crop which ranks third after wheat and rice in the world. Because of its expanded use in the agro-industries it is recognized as a leading commercial crop of great agro-economic value. In recent years, several new types of corn have been developed with improved nutritional traits. Feeding nutritionally enhanced grain may be a viable method to improve feed efficiency and reduce expensive fat and protein inputs for people (U.S. Grains Council 2002). This approach might allow producers to manage the cost/benefit ratio of feed ingredients more economically. Balanced nutrition is an essential component of nutrient management and plays a significant role in increasing crop production and its quality. Nitrogen is the motor of plant growth and vital component of protein and nucleic acids (Haque et al. 2001). A major consideration in successful high-quality grain production will be the effective use of $\mathrm{N}$ fertilizer to ensure high yields and optimize grain protein.

Many studies have shown that increasing $\mathrm{N}$ rates results in a higher crude protein concentration in conventional maize grain (Mason and Mason 2002). Unlike commodity grain production, profitability in nutritionally enhanced corn production is based not only on grain yield but also on the protein yield of the grain. A better understanding of the response of nutritionally enhanced maize genotype and $\mathrm{N}$ fertilization across varying growing conditions is needed to help growers make more profitable management decisions for optimizing growth, grain yield and protein content of maize.

The major objective of this study was to find out the effect of genotypes and nitrogen levels on growth, quality and yield of maize. Results of this research could help define $\mathrm{N}$ management practices best suited for nutritionally-enhanced maize genotypes that may elevate grain production on soils conducive to denitrification and $\mathrm{N}$ leaching during periods of prolonged saturation in kharif.

*Author for correspondence. <singhkaushalbhu@gmail.com>. ${ }^{1}$ Department of Agronomy, Institute of Agricultural Sciences, Banaras Hindu University, Varanasi 221005 India. ${ }^{2}$ Department of Genetics \& Plant Breeding, Institute of Agricultural Sciences, Banaras Hindu University, Varanasi 221005 India. 


\section{Materials and Methods}

A field experiment was conducted at Crop Research Center, Sardar Vallabhbhai Patel University of Agriculture and Technology, Modipuram, Meerut (Uttar Pradesh) (29 $05^{\prime} 19 " \mathrm{~N}$ and 77²41'50" E) during 2008-09.

The experiment was laid out in factorial RBD design with three replications. On succeeding maize crop, 25 treatment combinations comprising of five genotype $\left(\mathrm{V}_{1^{-}}\right.$Dekalb-Hishell, $\mathrm{V}_{2}$ - Dekalb-Double, $\mathrm{V}_{3}$ - Dekalb-900M-Gold, $\mathrm{V}_{4}$ - Dekalb-DKC-7074 and $\mathrm{V}_{5}$-Mahyco 3838) and five nitrogen levels were imposed. The crop was fertilized with nitrogen as per the treatment $(0$, 40, 80, 120 and $160 \mathrm{~N} \mathrm{~kg} / \mathrm{ha}$ ) and uniformly with 60-40-20 $\mathrm{P}_{2} \mathrm{O}_{5}, \mathrm{~K}_{2} \mathrm{O}$ and $\mathrm{ZnSO}_{4} \mathrm{~kg} / \mathrm{ha}$. Full dose of phosphorus (SSP) and potash (MOP) were applied as basal, while zinc sulphate was added at the time of last harrowing during field preparation. Nitrogen was applied in three equal splits as basal, knee-height and tasseling stages. Basal application of fertilizers was made at $8-10 \mathrm{~cm}$ depth in furrows opened $2-3 \mathrm{~cm}$ to the side of seed furrow. The seeds were placed manually in the furrows at a spacing of $60 \times 20 \mathrm{~cm}$ using the with recommended seed rate $(20 \mathrm{~kg} / \mathrm{ha})$ on June 29, 2008. Excess plants were thinned out at 21 days after sowing of the crop as to ensure intra-row spacing of $20 \mathrm{~cm}$. Weeding and irrigation were done as per crop requirements. LAI and photosynthetically active radiation (PAR) were measured with the help of PAR/LAI ceptometer (Accu PAR model LP-80). The correlation and regression studies were done to establish cause and effect relationship among quality and yield of maize. PARI (\%), protein content and protein yield were computed using the following formula:

$$
\text { PARI }(\%)=\frac{\text { PAR above canopy }- \text { PAR below canopy }}{\text { PAR above canopy }} \times 100
$$

\section{Results and Discussion}

A significant variation in respect of growth attributes viz., plant height, leaves/plant, dry matter accumulation/plant and leaf area index were recorded among the hybrids (Table 1). Among genotypes, Dekalb 900 M Gold accumulated higher dry matter/plant, LAI and cobs placed height than taller plant (Mahyco-3838). Observation recorded on photosynthetically active radiation (PAR) viz., PAR below canopy and photosynthetically active radiation interception indicated significant variation among genotypes. However, efficiently higher PAR below canopy and photosynthetically active radiation interception were observed under Dekalb DKC 7074 and Mhayco-3838, respectively (Table 1). Kumar et al. (2002) reported that inclusion of maize hybrids gave significantly higher growth attributing characters. Leaves/plant and PAR above canopy did not influence by genotypes.

Genotypes Dekalb Hishell required more days taken to 50\% tasseling and silking. All the genotypes remained at par in days taken to 50\% tasseling and silking except Mahyco 3838 (Table 1) which takes significantly fewer days to $50 \%$ tasseling and silking followed by Dekalb $900 \mathrm{M}$ Gold than other hybrids. The finding is in accordance with those of El-Sheikh (1999). Dekalb 900 M Gold yielded 31.6, 23.5, 10.6 and 4.6\% higher grain yield than Mahyco 3838, Dekalb Hishell, Dekalb Double and Dekalb DKC 7074, respectively and also gave significantly higher nitrogen content and protein content in grain, protein yield and protein productivity than other genotypes (Table 2).

Growth parameters viz., dry matter accumulation/plant, plant height, LAI and cobs placement height exhibited higher under highest levels of nitrogen (160 kg N/ha). Crop fertilized with $120 \mathrm{~kg}$ $\mathrm{N} / \mathrm{ha}$ remaining at par with those given 80 and $160 \mathrm{~kg} \mathrm{~N} / \mathrm{ha}$, but proved superiority over lower 


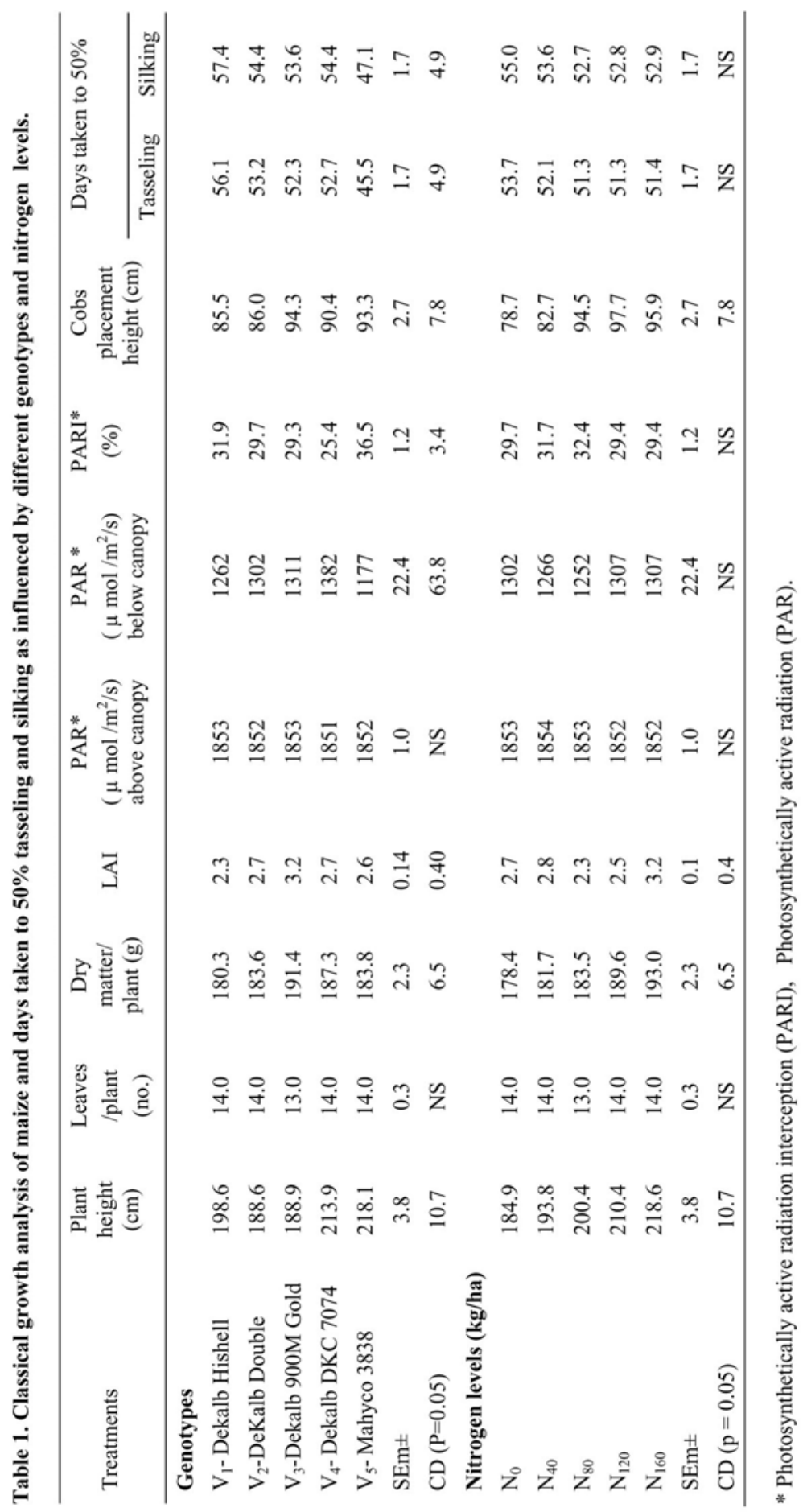


doses of nitrogen ( 0 and $40 \mathrm{~N} \mathrm{~kg} / \mathrm{ha}$ ) (Table 1$)$. Supply of adequate quantity of nitrogen might have enhanced the cell elongation, cell division, photosynthesis and translocation of photosynthates to respective part of growth and development and thus resulted in more plant height and dry matter accumulation (Dwivedi et al. 2009). The effect of applied nitrogen was found non-significant in respect of leaves/plant, PAR above and below canopy, photosynthetically active radiation interception and days taken to tasseling and silking. However, successive increase in nitrogen levels from 0 to $160 \mathrm{~kg} \mathrm{~N} / \mathrm{ha}$ caused decrease in days taken to tasseling and silking. The maximum days taken to tasseling and silking was noticed in control treatment. The application of nitrogen favours the growth and development of plants and resulted in early tasseling and silking (Sarma et al. 2000). Protein content, protein yield, protein productivity and grain yield increased significantly with increasing levels of nitrogen up to $120 \mathrm{~kg}$ N/ha (Table 2). Crop fertilized with $160 \mathrm{~kg} \mathrm{~N} / \mathrm{ha}$ had higher protein content in grain, protein yield and protein productivity than plant receiving no nitrogen, but at par with other levels of nitrogen (El-Hallof and Sarvari 2007). The differences were, however, non-significant in nitrogen content in grains. The application of $120 \mathrm{~kg} \mathrm{~N} / \mathrm{ha}$ registered significantly higher grain yield (6300 kg/ha), but at par with $160 \mathrm{~kg} \mathrm{~N} / \mathrm{ha}$ (6240 kg/ha), Sarma et al. (2000) observed that higher grain yield of maize was obtained with the application of $120 \mathrm{~kg} \mathrm{~N} / \mathrm{ha}$ as compared to lower levels of nitrogen.

Table 2. Quality and yield of maize grain as influenced by different genotypes and nitrogen levels.

\begin{tabular}{lccccc}
\hline Treatments & $\begin{array}{c}\text { N content } \\
\text { in grain } \\
(\%)\end{array}$ & $\begin{array}{c}\text { Protein } \\
\text { content } \\
(\%)\end{array}$ & $\begin{array}{c}\text { Protein } \\
\text { yield } \\
(\mathrm{kg} / \mathrm{ha})\end{array}$ & $\begin{array}{c}\text { Protein } \\
\text { productivity } \\
(\mathrm{kg} / \mathrm{ha} / \mathrm{day})\end{array}$ & $\begin{array}{c}\text { Grain yield } \\
(\mathrm{kg} / \mathrm{ha})\end{array}$ \\
\hline Genotypes & 1.4 & 9.0 & 463.5 & 4.5 & 5150 \\
$\mathrm{~V}_{1}$-Dekalb Hishell & 1.4 & 8.7 & 500.3 & 4.9 & 5750 \\
$\mathrm{~V}_{2}$-DeKalb Double & 1.9 & 12.0 & 763.2 & 7.5 & 6360 \\
$\mathrm{~V}_{3}$-Dekalb 900M Gold & 1.5 & 9.2 & 559.4 & 5.5 & 6080 \\
$\mathrm{~V}_{4}$-Dekalb DKC 7074 & 1.2 & 7.5 & 362.3 & 3.6 & 4830 \\
$\mathrm{~V}_{5}$-Mahyco 3838 & 0.1 & 0.5 & 2.6 & 0.4 & 24.1 \\
$\mathrm{SEm} \pm$ & 0.3 & 1.5 & 7.5 & 1.1 & 69.2 \\
$\mathrm{CD}(\mathrm{p}=0.05)$ & & & & & \\
$\mathrm{Nitrogen} \mathrm{levels} \mathrm{(kg/ha)}$ & 1.3 & 8.3 & 393.4 & 3.9 & 5740 \\
$\mathrm{~N}_{0}$ & 1.5 & 8.8 & 455.8 & 4.5 & 5180 \\
$\mathrm{~N}_{40}$ & 1.4 & 9.6 & 547.2 & 5.4 & 6300 \\
$\mathrm{~N}_{80}$ & 1.5 & 9.8 & 617.4 & 6.1 & 6240 \\
$\mathrm{~N}_{120}$ & 1.5 & 9.9 & 617.8 & 6.1 & 24.1 \\
$\mathrm{~N}_{160}$ & 0.1 & 0.5 & 2.6 & 0.4 & 69.2 \\
$\mathrm{SEm} \pm$ & $\mathrm{NS}$ & 1.5 & 7.5 & 1.1 & \\
$\mathrm{CD}(\mathrm{p}=0.05)$ & & & & & \\
\hline
\end{tabular}

Association among genotypes in respect of grain and protein yield was positively correlated with correlation co-efficient of 0.9826 and 0.9088 , respectively (Fig. 1a). Thus, each genotype caused improvement in grain and protein yield by 399 and $89.77 \mathrm{~kg} / \mathrm{ha}$, respectively (Fig. 1a). Regression analysis was also carried out to draw valid conclusion among nitrogen levels for grain and protein yield, which was positively correlated with correlation co-efficient of 0.9324 and 0.9375, respectively (Fig. 1b). However, increase in each levels of nitrogen (i.e. $40 \mathrm{~kg} \mathrm{~N} / \mathrm{ha}$ ) caused improvement in grain and protein yield by 412 and $61.04 \mathrm{~kg} / \mathrm{ha}$ (Fig. 1b) was also reported by Chaudhary et al. (2002). 


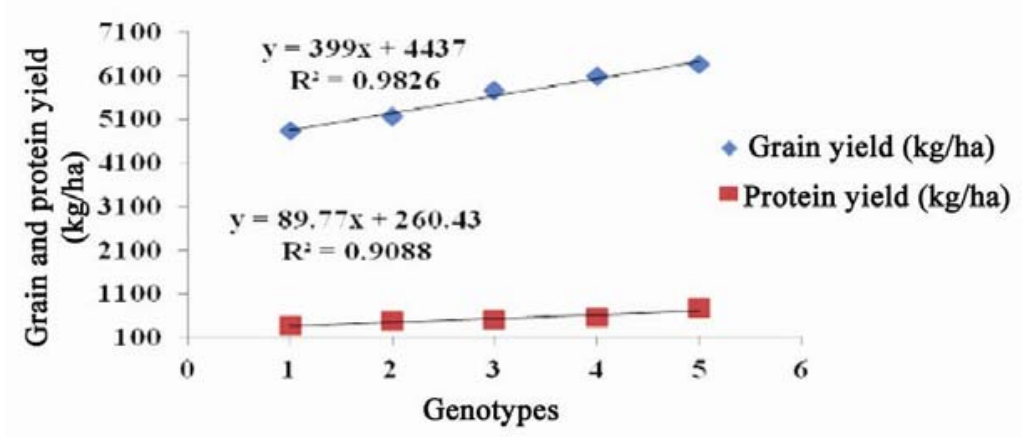

Fig. 1a. Regression of grain and protein yield of different genotypes 1 = Mahyco 3838, 2 = Dekalb Hishell, 3 $=$ DeKalb Double, $4=$ Dekalb DKC 7074 and $5=$ Dekalb 900M Gold.

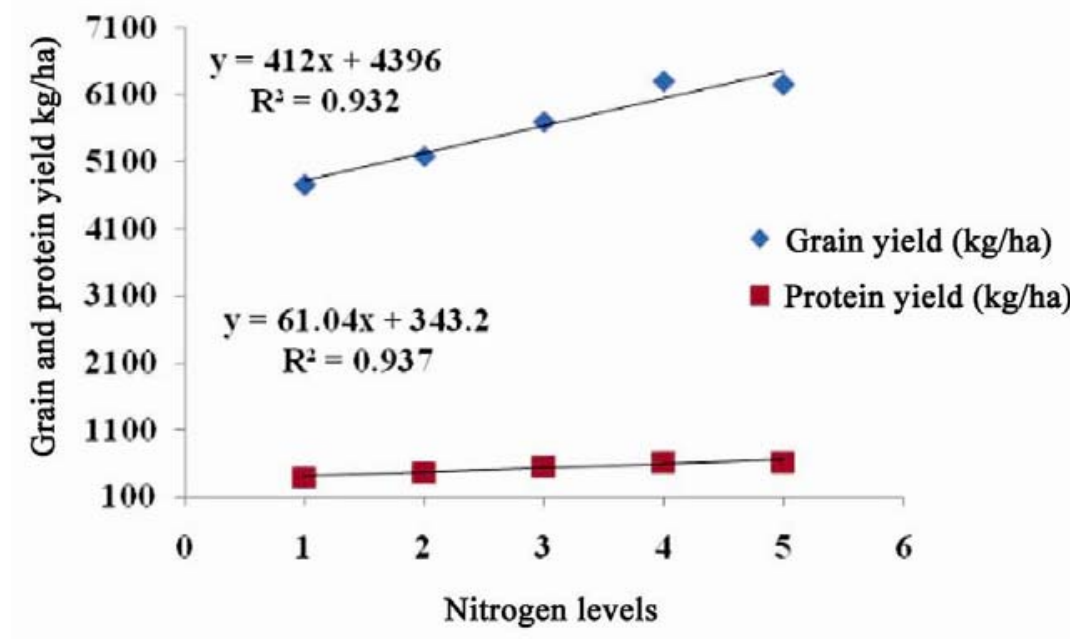

Fig. 1b. Regression of grain and protein yield of different nitrogen levels $1=\mathrm{N}_{0}, 2=\mathrm{N}_{40}, 3=\mathrm{N}_{80}, 4=\mathrm{N}_{120}, 5$ $=\mathrm{N}_{160}$ ).

Association among traits viz., yield and quality of maize as influenced by different genotypes and nitrogen levels measured by correlation coefficient revealed a significant and positive correlation. The grain yield of maize was significant and positively correlated with protein content $(\mathrm{r}=0.815$ and 0.976$)$, protein yield $(\mathrm{r}=0.913$ and 0.998$)$ and protein productivity $(\mathrm{r}=0.914$ and 0.998), respectively. However, cobs placement height did not showed significant association among traits viz. grain yield $(r=0.229)$, protein content $(r=0.349)$, protein yield $(r=0.364)$ and protein productivity $(\mathrm{r}=0.384)$, but it was significantly and positively correlated and influenced by nitrogen levels among traits viz., grain yield $(\mathrm{r}=0.967)$, protein content $(\mathrm{r}=0.987)$, protein yield $(r=0.978)$ and protein productivity $(r=0.978)$.

\section{References}

Choudhary RS, Rana KS and Kantwa KR 2002. Effect of cropping system and nitrogen on growth and yield of maize (Zea mays L.). Ann. Agril. Res. 23(3): 461-464. 
Dwivedi SK, Shrivastava GK, Singh AP and Shrivastava A 2009. Effect of integrated nitrogen management on root and shoot growth and yield of maize (Zea maize L.). Current Adv. Agril. Sci. 1(1): 4-7.

El-Hallof N and Sarvari M 2007. Relationship between yield quality and quality of maize hybrids and fertilizer. Cereal Res. Com. 35(2): 369-372.

El-Sheikh and F-T-Z 1999. Evaluation of seven maize varieties (Zea mays L.) for some growth characteristics, grain yield and its quality. Ann. Agril. Science 37(2): 881-896.

Haque MM, Hamid A and Bhuiyan NI 2001. Nutrient uptake and productivity as affected by nitrogen and potassium application levels in maize/sweet potato intercropping system. Korean J. Crop Sci. 46(1): 1-5.

Kumar A, Thakur KS and Manuja S 2002. Effect of fertility levels of promising hybrids maize (Zea mays L) under rainfed conditions of Himachal Pardesh. Ind. J. Agronomy 47(4): 526-530.

Mason SC and D’Croz-Mason NE 2002. Agronomic practices influence maize grain quality. J. Crop Prod. 5 : 75-91.

Sarma NN, Paul SR and Sarma D 2000. Response of maize (Zea mays L.) to nitrogen and phosphorus under rainfed conditions of the hills zone of Assam. Ind. J. Agronomy. 45(1): 126-131.

US Grains Council 2002. 2001-2002 value-enhanced grain quality report. U.S. Grains Council, Washington, D.C.

(Manuscript received on 10 February, 2013; revised on 3 December, 2013) 